\title{
Transition process to experience with elimination intestinal stoma: repercussions on body image
}

\section{Processo de transição para vivência com estomias intestinais de eliminação: repercussões na imagem corporal}

\section{Proceso de transición para vivir con eliminación de ostomía intestinal: repercusiones en la imagen corporal}

Nara Reisdorfer" ${ }^{*}$, Melissa Orlandi Honório Locks', Juliana Balbinot Reis Girondi', Lúcia Nazareth Amante1, Magali Schutz Corrêa

ORCID IDs

Reisdorfer N (D) https://orcid.org/ 0000-0002-5637-8649

Locks MOH (D) https://orcid.org/ 0000-0003-0972-2053

Girondi JBR (D) https://orcid.org/ 000-0002-37634176

Amante LN (D) https://orcid.org/ 0000-0002-5440-2094

Corrêa MS (D) https://orcid.org/ 000-0001-8289-0200
HOW TO CITE

Reisdorfer N, Locks MOH, Girondi JBR, Amante LN, Corrêa MS. Transition process to experience with elimination intestinal stoma: repercussions on body image. ESTIMA, Braz. J. Enterostomal Ther., 16: e1219. https://doi.org/10.30886/estima.v16.683_IN

\begin{abstract}
Objective: to know the process of transition and adaptation to the experience with elimination intestinal stoma. Methods: a descriptive-exploratory, mixed study conducted between May and July 2018 through a semi-structured interview and application of the body image scale with 13 people with a stoma, at the postoperative return in a federal hospital in the south of the country. The data analysis was by thematic categories and simple descriptive analysis. Results: The data showed a parity between the genders, mean age of 60.5 years, most parts married, with low education level, and away from work activities. The leading generator causes of stoma were neoplasias, stomas with more than six months, and temporary. The most frequently identified complications were intestinal loop prolapse and dermatitis. The most significant changes occurred in the food pattern, clothing, social behavior, and body image reflexes. The premorbid body subscale had an average of 22.23 points, and the subscale morbid body had an average of 15.15 points. Conclusion: The condition of being a person with a stoma has an impact on the way the individual sees their body. It is essential to highlight that individuals at risk of maladaptation are identified and addressed as early as possible.
\end{abstract}

DESCRIPTORS: Stoma; Body image; Nursing; Stomatherapy.

${ }^{1}$ Universidade Federal de Santa Catarina - Departamento de Ciências da Saúde - Florianópolis/SC - Brasil.

¿Universidade Federal de Santa Catarina - Hospital Universitário Polydoro Ernani de São Thiago - Florianópolis/SC - Brasil.

*Corresponding author: nara.reisdorfer@hotmail.com

Received: 18 Dec 2018 | Accepted: 12 Jun 2019 


\section{RESUMO}

Objetivo: Conhecer o processo de transição e adaptação para a vivência com estomia intestinal de eliminação. Métodos: estudo misto, descritivo-exploratório, realizado entre maio e julho de 2018 por meio de entrevista semiestruturada e aplicação da escala de imagem corporal com 13 pessoas com estomia, no retorno pós-operatório em um hospital federal no sul do país. A análise dos dados deu-se por categorias temáticas e análise descritiva simples. Resultados: os dados apontaram paridade entre os sexos, idade média de 60,5 anos, maioria casada, com baixo grau de instrução e afastada das atividades laborais. Causas principais geradoras do estomia foram as neoplasias, as estomias com mais de seis meses e as temporárias. As complicações mais identificadas foram prolapso de alça intestinal e dermatites. As mudanças mais significativas ocorreram no padrão alimentar, vestuário, comportamento social e reflexos na imagem corporal. A subescala corpo pré-mórbido teve média de 22,23 pontos e a subescala corpo mórbido teve média de 15,15 pontos. Conclusão: A condição de ser uma pessoa com estomia acarreta impacto na maneira como o indivíduo vê seu corpo. Ressalta-se a importância de que os indivíduos com risco de má adaptação sejam identificados e abordados o mais precocemente possível.

DESCRITORES: Estomia; Imagem corporal; Enfermagem; Estomaterapia

\section{RESUMEN:}

Objetivo: Conocer el proceso de transición y adaptación para la vivencia con eliminación de ostomía intestinal. Métodos: Un estudio mixto descriptivo y exploratorio, realizado entre mayo y julio de 2018 a través de entrevistas semiestructuradas y aplicando la escala de imagen corporal con 13 personas con ostomía, en el retorno postoperatorio en un hospital federal en el sur del país. Los datos fueron analizados por categorías temáticas y análisis descriptivo simple. Resultados: Los datos mostraron paridad de género, edad promedio de 60.5 años, mayormente casados, con baja educación y actividades fuera del trabajo. Las principales causas de la ostomía fueron neoplasias, ostomías mayores de seis meses y temporales. Las complicaciones más identificadas fueron prolapso de asa intestinal y dermatitis. Los cambios más significativos ocurrieron en los patrones dietéticos, la ropa, el comportamiento social y los reflejos de la imagen corporal. La subescala del cuerpo pre-mórbido promedió 22.23 puntos y la subescala del cuerpo mórbido promedió 15.15 puntos. Conclusión: Ser una persona con una ostomía tiene un impacto en la forma en que un individuo ve su cuerpo. La importancia de las personas en riesgo de mala adaptación debe identificarse y abordarse lo antes posible.

DESCRIPTORES: Ostomía; Imagen corporal; Enfermería; Estomaterapia.

\section{INTRODUCTION}

Elimination intestinal stomas have the purpose of temporarily or permanently to divert the intestinal transit for curative or palliative purposes when some part of the intestine presents dysfunction. Among the indications are colon and rectum neoplasias, diverticulitis, intestinal perforation, intestinal occlusion, fistulas, inflammatory bowel disease, and adenomatous polyposis ${ }^{1}$.

The process of making a stoma, be it in any portion of the intestine, temporary or definitive, requires specialized nursing care. People who need such a procedure have their life perspective altered, due to the fear of the surgical act, the doubts and desires of the life after that, besides the changes in the body image due to the presence of the stoma and the collector bag. Associated with this, there are changes in eating and hygiene habits, as well as the necessity for adaptation due to the use of some equipment, which can lead to changes in self-esteem, sexuality and, sometimes, social isolation ${ }^{2}$.

The body image is the person's perception of its own body, the figure created in mind and how it presents itself to each individual, varying lifelong, and can be influenced by the context in which the person is. It refers to the figure that one has in mind, of size, image, and shape, also expressing feelings related to these characteristics ${ }^{3}$.

Nursing, equipped with technical and scientific knowledge, can prepare the person for the surgical act, with clarification of doubts and support to emotional demands, in addition to all specialized care. It can also assist in the trans-operative and rehabilitation of this person, with support and referrals in the scope of social rights, in addition to empowering self-care with educational measures in order to improve the quality of life (QoL) of this population ${ }^{4}$.

Although people with a stoma may have characteristics in common, it is observed individualized, subjective needs, as a result of insecurities, resilience, and a fragile support network. The research is justified, therefore, to know the population that goes through such process allows the professionals to plan the care based on these data, as well as actions of health education and training of network professionals. The focus is on improving health care 
and, consequently, on individuals' QoL, respecting their individuality. Thus, the guiding question of the study was: "How does the process of transition and adaptation to the elimination intestinal stoma experience occur?". The objective was to know the process of transition and adaptation to the experience with elimination intestinal stoma.

\section{METHODS}

It is a study of a mixed character, of the descriptiveexploratory type. The study was developed in a university hospital located in the southern region of Brazil. The institution is public, conceived in the perspective of the trinomial teaching, research and extension, that attends to the local community and $18^{\text {a }}$ regional health of the state of Santa Catarina.

Participants in the study were adults with at least a three months old stoma who were on the outpatient care team of the proctology team who were approached for postoperative follow-up from May to July 2018. The invitation to participate in the research occurred on the return, at the moment in which the possible participant was waiting for the medical consultation. Upon acceptance, the interview occurred on the same day and in a private room at the clinic. The study complied with all the ethical precepts of Resolution $n^{\circ} 466 / 2012^{5}$, approved by the Committee of Ethics in Research with Human Beings under opinion no 1.788.494.

For data collector, a semi-structured interview was conducted with open and closed questions. To identify the sociodemographic profile, it was used the demographic variables of gender and age group. Also, it was sought to know the characteristics of the preparation of the stoma and the process of transition of adaptation and self-care. The interviews were recorded and later transcribed in full. After this collector technique, the body image scale was also applied "How I relate with my body" 6 .

The answers were obtained through a scale containing 14 items, of the Likert type, in which, in the form of affirmations, the agreement is investigated about some aspects of the body that the clients consider important, as they relate to the body and how they value their appearance. It is counted in ascending order: "Do not agree" = 1; "Little agree" = 2; "Moderately agree" = 3;
"Strongly agree" $=4$. The scores are obtained by the sum of the seven items, giving a score that varies between 7 and 28 in each of the scales, and the higher the score obtained, the better the relation with the body image.

The analysis of the qualitative data was given by thematic analysis ${ }^{7}$ that consists of three phases: the preanalysis, the organization of what is going to be analyzed; the exploration of the material through several readings; and treatment of the results, allowing the information obtained to be highlighted. The quantitative data of the body image scale were analyzed using descriptive statistics that involves the organization, the summary, and the representation of the data.

\section{RESULTS}

The study had 13 participants from the metropolitan region of Florianopolis, State of Santa Catarina. Parity between the genders was observed, and the majority of the participants had a mean age of 60.5 years, were married and had a low level of education, eight of whom had up to eight years of schooling. Although eight of the participants are under 60 , only one is inserted in the labor market, one autonomous without practicing the profession at the moment; the other participants are retired.

Regarding the generator cause of stoma, there was a high incidence of neoplasias (69\%), with the majority of participants have had a stoma for more than six months (46\%), although 10 with a temporary stoma. The primary type of stoma was colostomies (69\%), prevailing those of descending colon; the most common complications were intestinal loop prolapse and dermatitis peristome, with four participants presenting both complications.

The analysis of qualitative data allowed the construction of two categories: transition process, from diagnosis to living with a stoma; and elimination stoma: reflexes in body image, social interaction, and work.

\section{Transition process: from diagnosis to conviviality with the stoma}

The timing of the diagnosis of a clinical condition requiring extensive and potentially mutilating surgery can have a significant impact on people's lives. It was 
observed in the study that the notification was initially viewed negatively by the majority of the participants, but some demonstrated to understand it as a possibility of life maintenance.

"When the doctor said that he needed to put on, I cried, I knew at the time that I was going to surgery. I cried and thought, my God, something suspended in the belly. If the bag is for the necessity that I had, it is the greatest divine blessing to be able to put it. If it was not for this bag, I would not be here anymore." (P6)

"When I received the result of cancer, the doctor already said that he had to operate. I was kind of confused, and I did not want to put the bag. This is an inconvenience to me, and you can not admit to having a bag, you walk with the feces." (P13)

In the majority, nine of the participants were diagnosed with neoplasia, a grievance that carries a social burden of great suffering. Associated with the impact of this diagnosis and accompanied by the process of assimilation of the surgical necessity with the preparation of the stoma and postoperative recovery, they also need to pass by the chemotherapy treatment. This concern was identified in some participants, as described below.

"Of course, we are all going to die, that is for sure, we are already born knowing. However, cancer tells you a reality that I had not imagined before. I am going to die, and I am already the expiration date. Talked about cancer people think: this one is gone." (P4)

When asked about preoperative preparation and orientation, 11 of the study participants were informed before surgery that they would need a stoma. The other two performed the surgery in an emergency and did not have this information and was informed to the relative.

In the hospital space, the patient and its relatives have the first contact with the stoma. The first cleanings and exchanges of the collector equipment occur in this place, where the nursing team acts as a facilitator in the process of self-care. When questioned about the teaching provided by the nursing team, all the participants reported having received, being eight rated as very adequate, four as relatively adequate and one rated as not appropriate.
"From the nursing, we received all the instruction before being discharged, all the exchange process she was already teaching, the information was adequate, everything they said worked out." (P12)

Although there is a routine established for orientation and preparation before discharge, it is noticed that due to the excess of information, many are not absorbed. Preoperative guidance emerges as a viable alternative.

"Look, some things do, but I still have some difficulties, maybe they even talked, but many people get there, and there is a nutritionist, and this and that, it is much information, sometimes you can not get what you need. Sometimes it is so fast that the person can not assimilate. If you can do this before the surgery, the person has more time and begins to prepare." (P13).

Another aspect identified was the difficulties verbalized in the transition from hospital to home, being reported as a moment of significant change in the family structure. The family proved to be a great partner in this process of adaptation and experience with the stoma. Each participant and its family organization are unique, but in general, the spouse's stay as the primary caregiver was observed, since it assisted in direct care with the stoma and also in activities of daily living.

"If it were not my family, if it were not my wife and my daughter, I do not know what would become of me, that is the truth. They are everything to me, have no other definition.” (P4)

"Fortunately my husband is a very patient person, he understands everything, he stays in the hospital with me, but sometimes I wonder, my God, if it were another man, it would have disappeared. My husband does not work to take care of me." (P6)

When they arrived at home, the participants reported that they had encountered some difficulties in the care of their stoma and their equipment, requiring the help of relatives in some of the processes, usually referring to the exchange of the bag. Others report complete independence in the technical management of the stoma and adjuvant equipment. The most favorable adaptation of participants 
who had postoperative complications with long-term hospitalization was observed. Some had suture dehiscence or pressure lesions requiring surgical reintervention or daily healings.

"I left the hospital with a very big bedsore, three months of bed here in the hospital gave bedsore, and it cost to heal [...] I usually wash myself, and the exchange is when it starts to take off, so when there is necessity for wash, do the hygiene, I go there and do it. The difficulty I did not have much, I learned to clean easy." (P1)

\begin{abstract}
"The most serious difficulties are that at first, I wanted to walk, then the stoma came out, and we had to stop at the emergency [...] I am following the normal life, I adapted very fast, I did everything alone. I clean it hourly so that there is no risk of taking off or bursting, it is normal, I am used to it." (P9)
\end{abstract}

Participants experienced different realities in the process of adaptation. Much of it is with the closest support of family members in the adaptations of activities of daily living, care of the stoma, and emotional and financial support. Several changes in life habits were listed, among them the food process aimed at modulating the consistency of feces and reducing gas production. Changes also in the clothing model, opting for larger pieces, in order to disguise the collector equipment. Some participants reported confining themselves to the home environment, leaving only when necessary, reducing trips, trips to the beach, churches and the home of family and friends, due to the unpredictability of the eliminations.

"There was much change, and I did not drive anymore, I am not going to drive with this swaying. I did not travel anymore; I went to my beach house. I did not go anymore."(P1)

"The question about food also in the beginning, and we are very sad to leave some things aside $[. .$.$] now I go little in the$ church, which I had even a position, sat all the workers together, near, so I started to go there once in a while, except that I do not eat in the day, so I sit there behind the door." (P3)

"Another difficulty is that at home we always have a way to wash, but when I leave, I do not have a suitable place to wash that little bag." (P5)
"I had to buy wide clothing not to show up much, I did not get used to it." (P6)

\section{Elimination intestinal stoma: reflexes in body image, social interaction and work}

The process of adaptation and acceptance of an elimination stoma varies from person to person, influenced by culture, prior knowledge, fears, expectations, complications, and support network. Besides, the gender question emerged in the interviews as one of the influencing factors in this process. Some participants were more down and with reluctance to handle the collector equipment, both for cleaning and exchange, for the difficulty of acceptance, to see themselves as a person with a stoma.

“ I look myself half-hidden when I take off my shirt and see that there in front of the mirror, I do not stay, I am going to hide." (P2)

"It changed everything, so I do not live, everyone says it is a normal life, but it is not no. It might be for other people, but not for me. I knew a friend who had this, but he lived, he went to the bank, he drank beer, it was a nuisance, but for us, woman, I think it is always worse.” (P6)

Most of the participants reported that the elimination stoma interfered in the social life, either by the unpredictability of the effluent elimination or by the release of gases, noise, and odor, reporting that even with the activated carbon it is still possible to feel the odor, which causes embarrassment.

"You can not even go out, although I do not go out very much, I try to avoid a lot of agglomeration because of gases, these things are very embarrassing." (P3)

"Whether you like it or not, no matter how you disguise it, there is always have a rash here. People are watching you, you are sitting next to someone at the health clinic, whatever, that makes noise from here, it becomes difficult social." (P4)

Also, they reported the prejudice suffered as a result of the stoma, a factor that contributed to the even greater 
distancing of these participants from social life, seeking, in some cases, to approach the family more and more to meet the necessity for socialization. Others, in turn, sought independence for the stoma care, reporting feeling a burden for the relatives or infantilized, comparing the cleaning of the collector equipment with the diaper change in babies.

"For everyone, I met on the internet, I talked about everything I went through, that I had cirrhosis due to hepatitis and that I had my colostomy bags, so they blocked me. Some people stopped talking, I did not say anything else, I was speechless, so huge a prejudice.”(P10)

"I suffer a lot of embarrassment, one day they thought I was armed, but it was just the bag." (P11)

"It is sad, it is bad, because, you think, you are going back to being a child, you are dependent, you are dependent on people, and it is awful. It is difficult. My daughter is there with me, when I need, they take me, but everything is difficult, she stopped working to be with me here, it hurts me too." (P13)

The participants ended up moving away from almost every social life, even their work activities. Only one participant remained active in the field of work.

"I did not do my household tasks anymore, I was always doing something, I am a man who does not stop, I like to be moving, now I am more stopped, I was forced.” (P1)

"Look, today I am retired for disability, but I am an engineer. I had a company, I had to close the company, it is painful because you come in a situation that I feel is invalid like I could not do anything else.” (P13)

The experience with the stoma, the constraints, the distance from the leisure and work activities ended up affecting the perception of the participants' body image. As some participants reported adapting well to their stoma and equipment, reporting no changes in body image, others reported feeling incomplete and unable to look after their preparation, preferring death to the possibility of spending the rest of their lives with the stoma.
"The doctor said it is dangerous to do another surgery, which is almost four hours of surgery, it is a risk, that whole thing, but I would rather take that risk than live my life with it here." (P4)

"I want to do the surgery, I hope the doctor does not tell me it is forever. Otherwise, I will commit suicide, I will be unfortunate." (P10)

After the application of the body image scale, it was possible to identify some questions related to the perception of the image of the study participants. The body image subscale concerning the premorbid body had a maximum score of 28 points and a minimum of 7 points, with an average of 22.23 points. The subscale "morbid body" had a maximum score of 28 points and a minimum of 7 , with an average of 15.15 points (Tables 1 and 2).

It was observed that women seek to disguise more aspects of their body that they do not like, feel less attractive and physically more inhibited, but the numbers were not statistically significant. There have been reports of changes in sexual life because of difficulty in accepting and understanding the new body.

"All my life has changed, until the marriage, sex, no way, I am not comfortable, I am crazy to take off that bag and get back to normal.” (P6)

To address these issues, it was observed that the main confrontation strategies reported were the presence of family, religiousness, and hope of reconstruction of intestinal transit. The participants end up depositing their expectations in a possible reconstruction of transit.

"My strategies are the strength and courage to ask God for strength and courage. It is the way." (P6)

"I am confident that they will reverse all of this, that I will internalize and take it out. My strategy is to wait another week, and the doctor says that he will admit me and make a reversal. The strategy is hope." (P10)

How each person experiences this process of adaptation is unique and influenced by many characteristics, but it was observed that the family support, especially the 
Table 1. Responses of people attended at the outpatient clinic of the university hospital regarding the imaging subscale concerning the premorbid body. Florianopolis/SC, 2018.

\begin{tabular}{|c|c|c|c|c|}
\hline Item & $\begin{array}{l}\text { Do not } \\
\text { agree }\end{array}$ & $\begin{array}{l}\text { Agree } \\
\text { a little }\end{array}$ & $\begin{array}{c}\text { Agree } \\
\text { moderately }\end{array}$ & $\begin{array}{c}\text { Strongly } \\
\text { agree }\end{array}$ \\
\hline I consider that my body is an expression of "being man/woman." & 0 & 1 & 2 & 10 \\
\hline The body assumes more importance in a relationship between man and woman & 3 & 2 & 3 & 5 \\
\hline I can say that I like my body & 3 & 1 & 1 & 8 \\
\hline My partner likes my body & 2 & 0 & 2 & 9 \\
\hline I look with pleasure at my body & 5 & 1 & 0 & 7 \\
\hline I appreciate the image of my body & 1 & 0 & 1 & 11 \\
\hline I try to disguise aspects of my body that do not please me & 4 & 0 & 2 & 7 \\
\hline
\end{tabular}

Source: survey data, 2018.

Table 2. Responses of people attended at the outpatient clinic of the university hospital referring to the imaging subscale concerning the morbid body. Florianopolis/SC, 2018.

\begin{tabular}{|c|c|c|c|c|}
\hline Item & $\begin{array}{l}\text { Do not } \\
\text { agree }\end{array}$ & $\begin{array}{l}\text { Agree } \\
\text { a little }\end{array}$ & $\begin{array}{c}\text { Agree } \\
\text { moderately }\end{array}$ & $\begin{array}{c}\text { Strongly } \\
\text { agree }\end{array}$ \\
\hline I have felt inhibited concerning my appearance. & 3 & 0 & 3 & 7 \\
\hline I feel less physically attractive because of my illness and/or treatment. & 3 & 1 & 2 & 7 \\
\hline I have felt less masculine/feminine as a result of illness or treatment & 6 & 0 & 3 & 4 \\
\hline I find it hard to look at me when I am naked. & 5 & 0 & 4 & 4 \\
\hline I have felt less sexually attractive as a result of my illness or treatment & 3 & 1 & 2 & 7 \\
\hline I feel that the disease left my body incomplete. & 6 & 1 & 2 & 4 \\
\hline I have felt dissatisfied with the appearance of my stoma & 1 & 0 & 3 & 9 \\
\hline
\end{tabular}

Source: survey data, 2018.

spouse, the religiosity and the hope of the repairing surgical procedure were present in most speeches.

\section{DISCUSSION}

In Brazil, there is no official publication, in the last 10 years, with data such as profile, incidence, and prevalence related to the person with a stoma. For this reason, it was decided to systematize the data of some Brazilian studies that analyze the profile of people with a stoma in the last five years. The findings in the research performed resemble those of the literature of the last five years.

Most people with a stoma are men $^{8,-13}$, over 60 years of age $8,9,12,13$. Cancer was the causal factor of the surgery that generates the stoma ${ }^{8-14}$. The most frequent types were colostomies $^{8-11}$ temporary nature ${ }^{13,14}$ and permanent ${ }^{8,10}$.

The study ${ }^{13}$ showed that $53.6 \%$ had complications with the stoma, dermatitis peristome (37.1\%) and paracolostomic hernia (17.5\%), in a smaller number the intestinal loop prolapse (2.1\%), diverging from the findings in this study, in which prolapse was shown to be the main intercurrent. Regarding the level of education, the literature shows that there is a lower level of education, with the incomplete elementary level $1^{10,13,14}$ also observed in this research. As far as the relation with the work, a great distance of the labor activities is observed, being for the most retired or pensioners, generally with a minimum salary ${ }^{10,11,14}$. Taking into account the epidemiological profile of the study participants, the majority are under 60 years of age, and the return to the labor market is one of the aspects that should be considered.

Regarding the receipt of the medical diagnosis, it is known that the impact of any chronic health situation or mutilating surgical necessity is quite striking. When specifically dealing with the diagnosis of cancer, this in itself generates tensions for the cultural charge it carries. When it is associated with the necessity for 
stoma preparation, it has the potential to generate a traumatic experience in people's lives, both due to the limitations imposed by the condition, and by the beliefs and constraints experienced.

Care for this population covers innumerable interfaces that relate not only to physical and biological conditions but also to psychological changes in the intra and interpersonal relationships experienced in the transition process. Regarding the role of the nurse in the care of these people, this should be present in the pre-, trans- and postoperative phases, besides post-discharge follow-up in other levels of care. The preoperative phase comprises the moment when the decision of the surgical intervention is made until the referral to the operating room. During this period, nurses' performance is primordial, as it is crucial to perform a psychosocial and physical evaluation with a demarcation of the possible place of the stoma, in order to reduce difficulties in confrontation, prevent complications and achieve the best adaptation ${ }^{15}$.

It is essential to inform, in the preoperative, all those who will perform surgery, about the possibility of making a stoma, with the signing of the consent form, in addition to providing clarification for the family. The stoma marking should be performed by the stomatherapist nurse, with a view to the appropriate choice of place, facilitating self-care, autonomy, independence, and proper adhesion of the collector equipment. A retrospective, descriptive, multicenter study ${ }^{16}$ with 748 participants showed that the complication rate was higher among which the stoma site was not marked, compared to those whose stoma site was marked, 46 and $22.9 \%$, respectively.

The preparation of the person with a high stoma should be as early as possible, taking into account the transition process and self-care. Revision ${ }^{17}$, which analyzed 27 national and international studies, showed the main actions performed by nurses in preparation for hospital discharge: to advise on care with the stoma; skin peristome; collector equipment; nutrition, hydration and elimination; psychological support; and guidelines on physical and sexual activity. Among these guidelines, it is necessary to stimulate self-care, to provide written information on care, to include the caregiver/family in education, to use educational technologies compatible with the reality lived by each person, to advise on appropriate clothing and to advise on the use of analgesic drugs in pain case.
In this orientation process, the nurse needs to encourage the autonomy of the person with the stoma through practical knowledge focused on minimizing fears and uncertainties. The nurse presents itself as the professional who coordinates, welcomes, cares for, supports, and advises the process of transition, adaptation, and self-acceptance ${ }^{18}$.

The transition from hospital to home generates ambiguous feelings. At that moment, it feels like the happiness of returning home to theirs and insecurity with the new condition of life and absence of the professional to perform the care are added. Most of the time, the family begins the care of the stoma in the home and, gradually, it shares this care with the patient, according to its possibilities. The family presents itself as a source of support, reception, and care, both in the hospital and at home, and goes through every therapeutic itinerary of the person with the stoma. This allows the person to feel secure, fostering the feeling of belonging to the family system, as this family starts to have new needs for care, being essential that the nurse and the multidisciplinary team can identify and accept these demands ${ }^{19}$.

In addition to physical changes, individuals with elimination intestinal stoma experience changes in their routines, daily living activities, employment relationships, and social contacts. It was found, among the clients, a departure from daily activities, housework, leisure, and work activities. These factors can generate anxiety and other demands, taking into account the social and cultural importance of work, as a way of dignifying the subject. Associated with this, the financial dependence of retirement, often the necessity for financial assistance from family members, the change in the social function that was exercised within the family, as well as the weight of being considered unfit.

The literature corroborates the findings of the research, showing that having a stoma affects body integrity, functional capacity, social conviviality, and QoL, generating a high impact on daily life ${ }^{20}$. A study ${ }^{11}$ with 117 participants showed that $51.3 \%$ discontinued their work activities and $44.4 \%$ did not return, with retirement due to social security. Of the $48.7 \%$ who did not interrupt work activities, 33.3\% were retired, $13.6 \%$ were engaged in an unpaid activity, and $1.7 \%$ were selfemployed without the right to leave.

About intercourse with the stoma, a cross-sectional study ${ }^{20}$ with 635 participants showed that the average time to feel comfortable with the stoma was 214 days. 
Regarding adaptation, $39.6 \%$ had an excellent adaptation to the stoma, $67.7 \%$ had difficulty in self-care, needed help from relatives, and $50 \%$ reported some limitation to perform daily activities.

A significant number of the participants had no previous knowledge or contact with people with a stoma and had no conception of what a stoma is, the dimensions of the collector equipment, and the effluent disposal process. Strangeness before the new and unknown body reverberates in different ways in people with stomas and can influence how they see and self-conception.

Participants report insecurity, embarrassment, and discrimination with the stoma before society and the people that surround them. The new condition is seen as mutilating, altering the idea of perfect body imposed by contemporary society. The marginalization and prejudice on the part of those who consider themselves in the standards end up further distancing people with a stoma ${ }^{8}$.

Body image disorders are common in people with a stoma, and although they do not depend on physical changes to occur, there is a higher incidence in people with post-disabling procedures. Body image is characterized by the way the individual sees itself; changes in these perceptions directly interfere with self-esteem, which is the overall assessment of the individual expressed by self-approval or disapproval ${ }^{21}$.

Integrative review ${ }^{22}$ regarding the defining characteristics of body image disorder showed the significant presence of body image disorder in people with stomies, especially in women. The main changes observed in the literature were the actual change in the structure $(100 \%)$, reports of perceptions that reflect an altered vision in the body's appearance (88.4\%) and negative feelings about the body (79.1\%). These negative perceptions can lead to difficulty initiating or maintaining a relationship since the body is seen not only by the person with the stoma but also by its partner ${ }^{18}$.

As for the demographic factors, a significant correlation between body image disorders and age is observed, and younger people are more likely to develop body image disorders. This can occur because these individuals are more involved in social activities compared to the older ones. The literature also shows a significant rate of depression and anxiety in people with a stoma, with $43.9 \%$ of the 41 participants in the study presenting mild depressive symptoms and 29.3\% experiencing mild anxiety symptoms. Likewise, those who presented symptoms of depression, anxiety, and thoughts of self-injury also presented more significant impairment of body image $e^{21,23}$.

However, the factors that contribute to maladaptation to altered body image have not been studied. It is essential to know these factors in order to identify those who are at higher risk of developing image disorders. Besides, modifiable contributing factors can be corrected to help better fit body image ${ }^{23}$.

Acceptance of the stoma is by the sum of coping strategies, and several factors positively or negatively influence this adaptive process. Stable relationships with partner involvement in stoma care have a positive influence on body image perception. Lack of comorbidities, family support, access to health services, and hopeful feelings play a key role ${ }^{16,24}$.

The evaluation of the perception of the body image of the person with the stoma is becoming more and more critical, since the procedure provides a different experience, with changes in the patterns previously experienced ${ }^{25}$. It is essential to emphasize the importance of the multidisciplinary team focused on rehabilitation and transition in the most natural way possible. It is recommended to identify the risk factors for maladaptation in the preoperative period, to monitor these factors in the postoperative period and outpatient visits or home visits, in addition to evaluating depressive and anxiety symptoms. It is necessary to know and understand these factors to plan interventions that help the person deal with their new characteristics in a safe and secure manner ${ }^{23}$.

Despite the relevance of the data found, the research presents a limitation, such as the fact that it was developed in only one hospital and counted with a reduced number of participants. This study allowed visualizing the unfolding of the care, the transition process and the reflexes in the body image of a restricted group, the participants coming from a single macro-region that has support service to the person with a relatively wellstructured stoma. It is recommended that new studies be realized, thus expanding the population investigated and deepening the theme, in order to qualify care and potentiate the transition process, seeking to minimize body image disorders. 


\section{CONCLUSION}

The study made it possible to observe the innumerable physical, emotional, social and lifestyle modifications of the people with the stoma in their process of transition and adaptation, starting from a somber diagnosis, through the mutilating surgical procedure, to the experience with the stoma in the home and society. Changes in food patterns, clothing and social behavior, including withdrawal from work and leisure activities, and negative feelings and perceptions regarding the body with a stoma and new challenges to be experienced were observed. In this context, coping strategies are of high relevance. The family support, the religiosity, and the hope of the reconstruction of the intestinal transit were observed as decisive factors in this process.

The condition of being a person with a stoma has an impact on the way the individual sees their body. It has been observed that these seek to disguise aspects of their body that they do not like, feel less physically attractive and more inhibited, and report changes in sexual life because of difficulty in accepting and understanding the new body. There was a more favorable adaptation of the people with longer hospitalization time and who had the presence of family members, especially the spouse, in the care. People who stayed longer hospitalized generally passed more surgical procedures, a necessity for dressings and invasive devices, with the stoma being a coadjuvant in a negative experience. Already the involvement of the spouse in the care of this stoma made the patients feel more secure and accepted with their new characteristics.

It is essential to identify the individuals with maladaptation as early as possible so that they are monitored by psychology and approached for self-care. All follow-up should include pre and postoperative phases, as well as outpatient and home-based follow-up by the network. Nursing has a wide field of action and interventions in the care of these people, and the nurse can enhance the adaptation of the person with the stoma to the new condition of life and also promote social reintegration, through the reception of the demands, humanized technical support and necessary knowledge to develop potentialities, such as their self-care and autonomy.

\section{AUTHORS' CONTRIBUTION}

Conceptualization, Reisdorfer $\mathrm{N}$ and Locks $\mathrm{MOH}$; Methodology, Reisdorfer $\mathrm{N}$ and Locks $\mathrm{MOH}$; Investigation, Reisdorfer N; Writing - First version, Reisdorfer N and Locks MOH; Writing - Review \& Editing, Reisdorfer N, Locks MOH, Girondi JBR, Amante LN1 and Corrêa MS; Resources, Reisdorfer N and Locks MOH; Supervision, Locks MOH.

\section{REFERENCES}

1. Luz ALA, Luz MHBA, Antunes A, Oliveira GS, Andrade EMLR, Miranda SM. Perfil de los pacientes ostomizados: revisión integrativa de la literatura. Cul Cuid. 2014;18(39):115-23. https://doi.org/10.7184/cuid.2014.39.13

2. Mota MS, Gomes GC, Petuco VM. Repercussions in the living process of people with stomas. Texto Contexto Enferm. 2016;25(1):e1260014. https://doi.org/10.1590/0104070720160001260014

3. Schilder P. A imagem do corpo: as energias construtivas da psique. São Paulo: Martins Fontes; 1981.

4. Marques SG, Nascimento DC, Rodrigues FR, Lima CMF, Jesus DF. A vivência de pessoas com estomia intestinal no grupo de apoio em um Hospital Universitário. Revista HUPE. 2016;15(2):11321. https://doi.org/10.12957/rhupe.2016.28235

5. Ministério de Saúde. Conselho Nacional de Saúde (BR). Resolução n 466 de 12 de dezembro de 2012. Diário Oficial da União. Pag. 59.
6. Tapadinhas AR, Palhinhas P, Gouveia P. Validação da escala de imagem corporal "como me relaciono com o meu corpo": estudo com uma amostra de mulheres com cancro da mama. Actas do $6^{\circ}$ Congresso Nacional de Psicologia da Saúde Lisboa; Lisboa, Portugal. Instituto Superior de Psicologia Aplicada Edições; 2006.

7. MINAYO M. C. S. O desafio do conhecimento: pesquisa qualitativa em saúde. São Paulo: Hucitec; 2013.

8. Barbosa MH, Poggetto MTD, Barichello E, Cunha DF, Silva R, Alves PIC, et al. Aspectos clínicos e epidemiológicos de estomizados intestinais de um município de Minas Gerais. REAS. 2014:3(1):64-73.

9. Moraes JT, Assunção RS, Sá FS, Lessa ER, Corrêa LS. Perfil de pessoas estomizadas de uma região de saúde mineira. Enferm Foco. 2016;7(2):22-6. https://doi. org/10.21675/2357-707X.2016.v7.n2.788 
10. Miranda SM, Luz MHBA, Sonobe HM, Andrade EMLR, Moura ECC. Caracterização sociodemográfica e clínica de pessoas com estomia em Teresina. ESTIMA, Braz J Enterostomal Ther. 2016;14(1):29-35. https://doi.org/10.5327/Z18063144201600010005

11. Aguiar JC, Pereira APS, Galisteu KJ, Lourenção LG, Pinto $\mathrm{MH}$. Clinical and sociodemographic aspects of people with a temporary intestinal stoma. Rev Min Enferm. 2017;21:e1013. https://doi.org/10.5935/1415-2762.20170023

12. Barbosa MR, Simon BS, Tier CG, Garcia RP, Siniak DS, Rodrigues SO. Perfil de pessoas com estomias de um serviço de saúde municipal no Sul do Brasil. ESTIMA, Braz. J. Enterostomal Ther. 2018;16:e-1318. https://doi. org/10.30886/estima.v16.465_PT

13. Freitas JPC, Borges EL, Bodevan EC. Caracterização da clientela e avaliação de serviço de atenção à saúde da pessoa com estomia de eliminação. ESTIMA, Braz. J. Enterostomal Ther. 2018;16:e-0918. https://doi.org/10.30886/estima. v16.402_PT

14. Queiroz CG, Freitas LS, Medeiros LP, Melo MDM, Andrade RS, Costa IKF. Caracterização dos ileostomizados atendidos em um serviço de referência de ostomizados. Enferm glob. 2017;16(46):13-24. https://doi.org/10.6018/ eglobal.16.2.230551

15. Ribeiro RVL, Oliveira AC, Viana LVM, Pinto AP, Carvalho ML, Elias CMV. Adaptação social do paciente colostomizado: desafios na assistência de enfermagem. R Interd. 2016;9(2):216-22.

16. Baykara ZG, Demir SG, Karadag UM, Harputlu D, Kahraman UM, Karadag S, et al. A multicenter, retrospective study to evaluate the effect of preoperative stoma site marking on stomal and peristomal complications. Ostomy Wound Manage. 2014; 60(5):16-26.

17. Azevedo C, Faleiro JC, Ferreira MA, Oliveira SP, Mata LRF, Carvalho EC. Intervenções de enfermagem para alta de paciente com estomia intestinal: revisão integrativa. Rev Cuba Enferm. 2015;30(2).

18. Lima RA, Paulino EFR, Silva VMR, Loureiro AAS. Analisando produções científicas acerca da educação do enfermeiro estomaterapeuta na última década do século XXI. Rev Enferm Prof. 2014;1(2):462-70.

19. Mota MS, Gomes GC, Petuco VM, Heck RM, Barros EJL, Gomes VLO. Facilitadores do processo de transição para - autocuidado da pessoa com estoma: subsídios para Enfermagem. Rev Esc Enferm USP. 2015;49(1):82-8. https:// doi.org/10.1590/S0080-623420150000100011

20. Silva CRDT, Andrade EMLR, Luz MHBA, Andrade JX, Silva GRF. Quality of life of people with intestinal stomas. Acta Paul Enferm. 2017;30(2):144-51. https://doi.org/10.1590/1982-0194201700023

21. Hong KS, Oh B, Kim E, Chung SS, Kim KH, Lee R. Psychological attitude to self-appraisal of stoma patients: prospective observation of stoma duration effect to self-appraisal. Ann Surg Treat Res. 2014;86(3):152-60. https://doi.org/10.4174 \%2Fastr.2014.86.3.152

22. Costa IKF, Liberato SMD, Freitas LS, Melo MDM, Sena JF, Medeiros LP. Distúrbio na imagem corporal: diagnóstico de enfermagem e características definidoras em pessoas ostomizadas. Aquichan. 2017;17(3):270-83. https://doi. org/10.5294/aqui.2017.17.3.4

23. Jayarajah U, Samarasekera DN. Psychological adaptation to alteration of body image among stoma patients: a descriptive study. Indian J Psychol Med. 2017;39(1):63-8. https://doi.org/10.4103/0253-7176.198944

24. Aktas D, Gocman BZ. Body image perceptions of persons with a stoma and their partners: a descriptive, crosssectional study. Ostomy Wound Manage. 2015;61:26-40.

25. Salomé GM, Almeida SA, Silveira MM. Quality of life and self-esteem of patients with intestinal stoma. J Coloproctol. 2014;34(4):231-9. https://doi.org/10.1016/j.jcol.2014.05.009 